JAMP: Jurnal Adminitrasi dan Manajemen Pendidikan

Volume 3 Nomor 1 Maret 2020, Hal : 72-83

Tersedia Online di http://journal2.um.ac.id/index.php/jamp/

ISSN 2615-8574 (online)

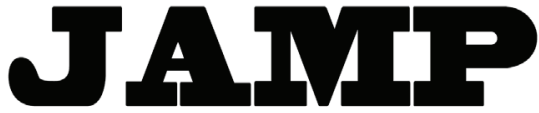

JURNAL ADMINISTRASI DAN MANAJEMEN PENDIDIKAN

\title{
MANAJEMEN PEMBELAJARAN SEKOLAH DASAR DI DAERAH TERTINGGAL
}

\author{
Agus Yanto \\ Ali Imron \\ Djum Djum Noor Benty \\ Universitas Negeri Malang \\ J1. Semarang, No. 5 Malang \\ E-mail: agusyantoumfiap16@gmail.com
}

\begin{abstract}
Research aimed at describing; (1) the preparation of learning programs, (2) implementation of learning programs, (3) evaluation of learning programs, (4) learning support factors, (5) learning inhibiting factors, and (6) efforts / solutions regarding learning inhibiting factors. This study uses a qualitative approach to the type of descriptive case study research. The conclusions of this study: (1) the preparation of learning programs using a dual curriculum namely K13 and KTSP, (2) the implementation of learning programs administratively using two curricula namely K13 and KTSP. However, due to the good condition of the school condition of the condition of the facilities and prasanan and also the condition of the students so that the learning process is closer to using KTSP, (3) evaluation of the learning program conducted by the teacher there are two types of learning evaluation namely summative evaluation which is meant summative evaluation namely evaluation conducted by the teacher in order to determine the results and development or progress of student learning, and also in addition to summative evaluation the teacher also uses formative evaluation which is an evaluation conducted by the teacher in order to improve and enhance the learning and teaching process, (4) there are two factors supporting learning the first source is the school's internal environment and also the school's external environment, (5) there are two factors that inhibit learning, the first is from the school's internal environment and also the school's external environment, (6) efforts / solutions regarding learning inhibiting factors are two ways that schools do in $\mathrm{m}$ handle learning barriers that is dependent on the source of the obstacles. Efforts or solutions made by schools in dealing with the lack of facilities and infrastructure is to ask for more help from the government or the Office of Education.
\end{abstract}

Keywords: management, learning, elementary school, disadvantaged remote area

Abstrak: Penelitian ini bertjuan mendeskripsikan; (1) penyusunan program pembelajaran, (2) implementasi program pembelajaran, (3) evaluasi program pembelajaran, (4) faktor pendukung pembelajaran, (5) faktor penghambat pembelajaran, dan (6) upaya/solusi mengenai faktor penghambat pembelajaran. Penelitian ini menggunakan pendekatan kualitatif dengan jenis penelitian studi kasus deskriptif. Simpulan penelitian ini: (1) penyusunan program pembelajaran menggunakan kurikulum ganda yaitu K13 dan KTSP, (2) implementasi program pembelajaran secara administrasi menggunakan dua kurikulum yaitu K13 dan KTSP. Akan tetapi karena kondisi sekolah baik dari faktor kondisi sarana dan prasanan dan juga faktor Keadaan siswa sehingga pada proses pembelajaran lebih dekat dengan menggunakan KTSP, (3) evaluasi program pembelajaran yang dilakukan guru ada dua jenis evaluasi pembelajaran yaitu evaluasi sumatif yang mana dimaksudkan evaluasi sumatif yaitu evaluasi yang dilakukan oleh guru guna untuk menentukan hasil dan perkembangan atau kemajuan belajar siswa, dan juga selain evaluasi sumatif guru juga menggunakan evaluasi formatif yaitu evaluasi yang dilakukan oleh guru guna untuk memperbaiki dan meningkatkan proses belajar dan mengajar, (4) faktor pendukung pembelajaran ada dua sumber yang pertama dari lingkungan internal sekolah dan juga lingkungan eksternal sekolah, (5) faktor penghambat pembelajaran ada dua sumber yang pertama dari lingkungan internal sekolah dan juga lingkungan eksternal 
sekolah, (6) upaya/ solusi mengenai faktor penghambat pembelajaran ada dua cara yang dilakukan sekolah dalam menangani hambatan pembelajaran yaitu tergantung dari sumber hambatan. Upaya atau solusi yang dilakukan sekolah dalam menangani kekurangan sarana dan prasarana yaitu dengan meminta bantuan lebih kepada pemerintah atau Dinas Pendidikan.

Kata kunci: manajemen, pembelajaran, sekolah dasar, daerah tertinggal

Pelaksanaan pendidikan di Indonesia pada satuan pendidikan, baik daripendidikan dasar sampai dengan perguruan tinggi atau pendidikan tinggi bahkan pendidikan formal maupun informal pada hakekatnya dapat menjadi acuan atau landasan dalam pembentukan karakter peserta didik menjadi lebih baik (Mulyasa, 2016:13).

Berdasarkan hasil penelitian oleh Ferri, dkk (2017:228) menunjukkan bahwa kegiatan perencanaan, meliputi penyusunan Rencana Program Pembembelajaran (RPP), penyusunan silabus, penyusunan Program Tahunan dan Program Semesteran. Perencanaan pembelajaran tertuang dalam RPP yang dipersiapkan oleh masing-masing guru kelas. Pembelajaran pada sekolah dasar yang menyajikan konsep-konsep dari berbagai mata pelajaran dalam suatu proses pembelajaran. Dengan demikian, siswa mampu memahami konsep-konsep tersebut secara utuh. Hal ini, diperlukan untuk membantu siswa dalam memecahkan masalah-masalah yang dihadapi dalam kehidupan sehari-hari. Menurut Kementrian Negara Pembangunan Daerah Tertinggal RI (2007) penentuan kriteria daerah tertinggal menggunakan pendekatan enam kriteria yaitu: (1) perekonomian masyarakat, (2) sumberdaya manusia,(3) prasarana dan sarana, (4) kemampuan keuangan daerah, (5) aksesibilitas dan (6) karakteristik daerah

Berdasarakan penelitian pendahuluan hasil observasi, wawancara, dan dokmentasi. Manajemen Pembelajaran di Sekolah Dasar Negeri 14 Mentarau, Kecamatan Teluk Batang, Kabupaten Kayong Utara, Provinsi Kalimantan Barat. Hasil observasi lapangan bahwa proses pembelajaran di sekolah masih menggunakan cara yang konvensional, guru masih banyak menggunkan metode mengajar dengan ceramah, media yang dugunkan juga hanya menggunakan papan tulis. Pembicaraan masih didominasi oleh guru para siswa tidak begitu aktif dalam proses pembelajaran, hanya beberapa siswa yang mengajukan pertanyaan.

fokus penelitian yang akan diteliti adalah: (1) penyusunan program pembelajaran, (2) implementasi program pembelajaran, (3) evaluasi program pembelajaran, (4) faktor pendukung pembelajaran, (5) faktor penghambat pembelajaran, (6) upaya/solusi menangani faktor penghambat pembelajaran.

Tujuan penelitian yang akan diteliti adalah: (1) mendeskripsikan penyusunan program pembelajaran, (2) mendeskripsikan implementasi program pembelajaran, (3) mendeskripsikan evaluasi program pembelajaran, (4) mendeskripsikan faktor pendukung, (5) mendeskripsikan faktor penghambat pembelajaran, (6) Mendeskripsikan upaya/solusi mengenai faktor penghambat pembelajaran.

\section{METODE}

Penelitian ini menggunakan pendekatan kualitatif dengan jenis penelitian studi kasus deskriptif di SDN 14 Mentarau dengan teknik pengumpulan data menggunakan teknik observasi, wawancara, dan dokumentasi. Wawancara berupa informan Kepala Sekolah, guru mata pelajaran, dan guru yang menjabat sebagai wali kelas IV. Selanjutnya analisis data dengan kondensasi data, berarti peneliti membuat ikhtisar hasil pengumpulan data selengkapnya dan kemudian memilah-milah data sesuai dengan fokus penelitian. Seperangkat hasil kondensasi data, juga diorganisir ke dalam suatu bentuk sajian tertentu (data display), sehingga terlihat sosoknya secara utuh, Sajian data berbentuk catatan wawancara, catatan observasi, dan catatan dokumentasi. Dengan sajian data yang demikian, maka akan memudahkan upaya pemaparan data penegasan simpulan (conclusion drawing and verifying). 


\section{HASIL}

Hasil peneliti terkait manajemen pembelajaran sekolah dasar di daerah tertinggal

\section{Penyusunan Program Pembelajaran}

SDN 14 Mentarau menggunakan kurikulum ganda yaitu Kurikulum 2013 penerapannya diterapkan di kelas I dan IV, sedangkan pada di kelas II, III, V , dan VI menerapkan KTSP. Pembelajaran menggunakan buku tematik dan juga buku mata pelajaran, buku tematik dan juga buku mata pelajaran digunakan pada kelas yang menerapkan Kurikulum 2013, sedangkan kelas yang menerapkan KTSP hanya menggunakan buku mata pelajaran. Instrumen perangkat pembelajaran berupa Silabus, RPP, program tahunan, dan juga program semester. Silabus pada Kurikulum 2013 merupakan silabus yang berasal dari pemerintah pusat atau Dinas Pendidikan pusat, akan tetapi sekolah juga mengembangkan sesuai dengan kondisi sekolah. Sedangkan pada KTSP menggunakan silabus yang dibuat oleh sekolah guna menyesuaikan dengan keadaan dan kondisi sekolah. RPP merupakan pengembangan dari silabus yang telah dibuat atau yang telah dikembangkan oleh sekolah, Rancangan program pembelajaran dibuat oleh guru yang berangkutan, baik melalui KKG, maupun secara individu.

\section{Implementasi Program Pembelajaran}

Sekolah Dasar Negeri 14 Mentarau secara administrasi menggunakan dua Kurikulum yaitu kurikulum 2013 dan KTSP. Akan tetapi karena kondisi sekolah baik dari faktor kondisi sarana dan prasanan dan juga faktor Keadaan siswa sehingga pada proses pembelajaran lebih dekat dengan menggunakan KTSP. Pendekatan pada proses implementasi program pembelajaran guru menggunakan pendekatan konsep, pendekatan proses, dan pendekatan kontekstual. Proses pembelajaran di dalam kelas strategi-strategi pembelajaran yang digunakan oleh guru sangat bervariasi yaitu cara mengatur tempat duduk siswa memasang-masangkan siswa dan juga posisi bangku siswa guna menciptakan kondisi yang kondusif pada saat pembelajaran, kemudian dari pada itu guru juga menggunakan strategi mencari referensi sumber belajar yang sesuai dengan materi yang akan disampaikan, dan guru juga melakukan penilaian yang bertujuan untuk mengetahui perkembangan dan kemampuan siswa. Pada saat menyampaikan materi pembelajaran atau pada saat mengajar metode pembelajaran yang digunakan guru dalam mengajar berupa metode ceramah dengan berbicara di depan kelas atau menjelaskan materi kepada siswa secara lisan, selain metode ceramah guru juga menggunakan metode tanya jawab dengan cara memberikan pertanyaan kepada siswa kemudian guru juga memberikan kesempatan kepada siswa untuk menjawab pertanyaan dari teman-teman sekelasnya yang kemudian jawaban dari siswa-siswa akan diperkuat atau diperjelas lagi oleh guru, guru juga memberikan penugasan terstruktur kepada siswa guna menggukur sejauh mana kemampuan siswa dalam menyerap pembelajaran yang telah disampaikan. Untuk mengasah atau melatih kemampuan siswa guru menggunakan metode latihan, dan metode diskusi kelompok.

\section{Evaluasi Program Pembelajaran}

Evaluasi pembelajaran yang dilakukan guru Sekolah Dasar Negeri 14 Mentrau ada dua jenis evaluasi pembelajaran yaitu evaluasi sumatif yang mana dimaksudkan evaluasi sumatif yaitu evaluasi yang dilakukan oleh guru guna untuk menentukan hasil dan perkembangan atau kemajuan belajar siswa, dan juga selain evaluasi sumatif guru juga menggunakan evaluasi formatif yaitu evaluasi yang dilakukan oleh guru guna untuk memperbaiki dan meningkatkan proses proses belajar dan mengajar.

Proses evaluasi pembelajaran pada siswa guru menggunakan alat atau bentuk evaluasi pembelajaran berupa bentuk test lisan, yang dimaksudkan dengan test lisan disini yaitu guru memberikan pertanyaanpertanyaan terkait materi pembelajaran yang telah disampaikan, selain test lisan guru juga menngunaka test tertulis berupa memberikan tugas untuk mengerjakan soal-soal pilihan berganda maupun soal jawaban uraian yang biasanya dilakukan pada kegiatan ulangan harian, ulangan tengah semester (UTS), dan juga ulangan akhir semester (UAS). Aspek-aspek yang di evaluasi berupa aspek proses pembelajaran siswa guna melihat partisipasi siswa dalam menikuti pembelajaran atau kehadiran siswa, dan keaktifan siswa dalam proses belajar, kemudian guru juga mengevaluasi dari aspek sikap siswa mengenai kedisiplinan siswa terhadap aturan sekolah, sikap menghormati guru dan sesame teman, dan juga aspek pengetahuan siswa meliputi daya serap siswa terhadap pembelajaran. 


\section{Faktor Pendukung Pembelajaran}

Faktor pendukung pembelajaran ada dua sumber yang pertama dari lingkungan internal sekolah dan juga lingkungan eksternal sekolah. Pembelajaran di sekolah tidak terlepas dari adanya Faktorfaktor pendukung pembelajaran. Di Sekolah Dasar Negeri 14 Mentarau ada beberapa faktor pendukung pembelajaran baik yang bersumber dari lingkungan internal sekolah maupun yang bersumber dari lingkungan eksternal sekolah. Faktor pendukung yang bersumber dari lingkungan internal sekolah meliputi dari faktor guru yang secara kompetensi sudah lulusan S1 semua dan juga dalam proses guru mengajar mempunyai kreatifitas masing-masing guru yang sesuai dengen kondisi di dalam kelas.

Kemudian selain dari faktor guru juga ada dari faktor siswa yang antusiasnya dalam menuntut ilmu mempunyai motivasi yang bagus sehingga dalam kondisi dan keadaan akses jalan atau cuaca para siswa tetap datang kesekolah walaupun harus berjalan kaki dengan jarak dari rumah ke sekolah yang cukup jauh, Peran siswa dalam mendukung pembelajaran secara IPTEK daya dukung masih kurang dan untuk faktor pendukung selanjutnya yaitu dari faktor sarana dan prasarana sekolah. Sarana dan prasarana di Sekolah Dasar Negeri 14 Mentarau dari segi bangunan sudah memiliki bangunan sendiri walaupun bangunannya sudah tua, akan tetapi juga telahdi bangun beberapa lokal baru untuk dijadikan ruangan kelas, Sarana dan prasarana dalam menunjang proses pembelajaran masih jauh dari pada kata cukup, masih banyak kekurangan baik dari segi sarana maupun prasarananya kemudian darri segi sarana dan prasarana yang menunjang proses pembelajaran lainya tetap menjadi faktor pendukung pembelajaran walaupun sekolah hanya memiliki sarana dan prasarana yang ala kadarnya. Kemudian selain faktor internal juga ada faktor eksternal yang mendukung pembelajaran yang meliputi dari dukungan masyarakat dan dunia usaha dan industri salah satunya dari perusahaan kelapa sawit.

\section{Faktor Penghambat Pembelajaran}

Faktor penghambat pembelajaran ada dua sumber yang pertama dari lingkungan internal sekolah dan juga lingkungan eksternal sekolah. Faktor penghambat yang bersumber dari lingkungan internal sekolah berupa kurangnya sarana dan prasarana, sarana dan prasarana sekolah masih ala kadarnya masih jauh dari kata memenuhi standar, kemudian faktor penghambat lainnya juga dari faktor kurangnya daya dukung IPTEK siswa, secara umum pengetahuan umum siswa masih kurang, siswa juga masih belum bisa menyerap teknologi, dan juga belum bisa sepenuhnya bisa mencari tahu atau mengakses hal-hal atau perkembangan dunia luar, pengetahuan siswa hanya sebatas di sekitar tempat tinggal mereka, selian faktor sarana dan prasarana juga faktor penghambat pembelajaran yang disebabkan seringnya guru datang terlambat mengajar pada saat cuaca hujan atau pada saat musim hujan karena di pengaruhi oleh faktor akses jalan yang rusak.

Sedakngkan faktor penghambat yang bersumber dari lingkungan eksternal sekolah berupa akses jalan, kebijakan kurikulum, dan juga kurangnya daya dukung masyarakat sekitar dalam mendukung proses pembelajaran atau menjaga keamanan lingkungan sekolah.

\section{Upaya/Solusi Menangani Faktor Penghambat Pembelajaran}

Cara yang dilakukan sekolah dalam menangani hambatan pembelajaran yaitu tergantung dari sumber hambatan. Upaya atau solusi yang dilakukan sekolah dalam menangani kekurangan sarana dan prasarana yaitu dengan meminta bantuan lebih kepada pemerintah atau Dinas Pendidikan. Upaya yang dilakukan sekolah atau guru untuk mengatasi kekurangan media pembelajaran yaitu dengan cara membuat media pembelajaran sendiri atau dengan cara meminjam sesam guru di sekolah lain. Mengatasi kurangnya daya dukung IPTEK siswa pihak sekolah melakukan sosialisasi kepada orang tua siswa agar memperhatikan proses pembelajaran siswa. Untuk mengatasi akses jalan yang rusak yang menjadi penyebab guru sering terlambat masuk mengajar yaitu dengan cara menyampaikan keluhan baik secara lisan maupun dengan memposting Keadaan jalan ke media massa atau internet. Sedangkan untuk mengatasi kebijakan kurikulum atau perubahan kurikulum guru mengikuti pelatihan. 


\section{PEMBAHASAN}

\section{Penyusunan Program Pembelajaran}

Berdasarkan temuan penelitian yang sudah dipaparkan sebelumnya bahwa SDN 14 Mentarau Menggunakan kurikulum ganda yaitu Kurikulum 2013 dan KTSP. Kurikulum 2013 penerapannya diterapkan di kelas I dan IV, sedangkan di kelas II, III, V, dan kelas VI menerapkan KTSP. Merujuk pada UU No. 23 Tahun 2003 Tentang Sistem Pendidikan Nasional bahwa satuan pendidikan sekolah dasar mempunyai kurikulum untuk mencapai tujuan pembelajaran, senada dengan Susanto (2008:15)," Kurikulum adalah suatu dokumen tentang program pendidikan atau pelatihan yang memberikan tujuan umum program dan tujuan umum setiap mata pelajaran yang dipersyaratkan di dalam kurikulum", sejalan dengan itu menurut (Susanto, 2007),"KTSP merupakan suatu dokumen yang memuat rencana penyelenggaraan dan pengembangan sekolah.

Kurikulum sekolah dasar disusun berdasarkan analisis ketentuan kompetensi yang akan dicapai. Yang dimaksud dengan ketercapaian kompetesnsi yaitu kurikulum adalah seperangkat rencana dan pengetahuan menegenai isi dan bahan pelajaran serta cara atau pedoman dalam implementasi kegiatan pembelajaran sehingga Sekolah Dasar Negeri 14 Mentarau menggunakan kurikulum ganda yaitu Kurikulum 2013 dan KTSP menurut Triwiyanto (2014: 3)," Kurikulum sebagai pedoman penyelenggaraan kegiatan pembelajaran memberikan makna bahwa di dalam kurikulum terdapat paduan interaksi antara guru dan siswa". Sedangkan menurut Widyastono (2015)," Kurikulum 2013 pada Sekolah Dasar sekurang-kurangnya wajib memuat kajian pembelajaran tentang; 1). Bagian A; Pendidikan Agama dan Budi Pekerti, Pendidikan Pancasila dan Kewarganegaraan, Bahasa Indonesia, Matematika, Ilmu Pengetahuan Alam (IPA), dan Ilmu Pengetahuan Sosial (IPS), 2) Bagian B; Seni Budaya dan Prakarya, dan Pendidikan Jasmani, Olahraga, dan Kesehatan". Berdasarkan dengan apa yang dipaparkan oleh Triwiyanto dan Widyastono Sekolah Dasar Negeri 14 Mentarau pembelajaran menggunakan buku tematik dan juga buku mata pelajaran, buku tematik dan juga buku mata pelajaran digunakan pada kelas yang menerapkan Kurikulum 2013, sedangkan kelas yang menerapkan Kurikulum Tingkat Satuan Pendidikan (KTSP) hanya menggunakan buku mata pelajaran. Dalam penerapan Kurikulum 2013 maupun KTSP perlu terlebih dahulu menyusun instrumen perangkat pembelajaran. Hal ini selaras dengan pendapat Akbar (2013:7) menyatakan bahwa kurikulum Indonesia pada saat ini menerapkan Kurkulum 2013 yang mana pengembangan silabus berbasis pada kompetensi penyususnan silabus (minimal) sangat memungkinkan untuk disusun oleh pemerintah pusat, akan tetapi pada pengembangan silabus juga perlu disesuaikan dengan kondisi lingkungan belajar di daerah atau di tempat terselenggaranya pendidikan. Silabus merupakan acuan dalam menyusun RPP yang memuat identitas mata pelajaran (tema pelajaran), Standar Kompetensi (SK), Kompetensi Dasar (KD), materi pelajaran, indicator ketercapaian kompetensi, penilaian, alokasi waktu, dan sumber belajar.

Panduan Implementasi Standar Proses untuk Satuan Pendidikan Dasar dan Menengah (2009) menyatakan silabus sebagai acuan pengembangan RPP memuat identitas mata pelajaran atau tema pelajaran, Standar Kopetensi (SK), Kompetensi Dasar (KD), materi pelajaran, kegiatan pembelajaran, indicator pencapaian kompetensi, penilaian alokasi waktu, dan sumber belajar. Pengembangan silabus berdasarkan acuan standar isi, dan standar kelulusan. Pelaksanaan pengembanagn silabus dapat dilakukan dengan sendiri oleh guru, kelompok guru dan beberapa sekolah (MGMP, KKG), dan Dinas Pendidikan.

Berdasarkan apa yang telah dipaparkan sebelumnya bahwa Sekolah Dasar Negeri 14 Mentarau menyusun instrumen perangkat pembelajaran berupa Silabus, RPP, Program Tahunan, dan juga Program Semester. Silabus pada Kurikulum 2013 merupakan silabus yang berasal dari pemerintah pusat atau Dinas Pendidikan pusat, akan tetapi sekolah juga mengembangkan sesuai dengan kondisi sekolah. Sedangkan pada KTSP menggunakan silabus yang dibikin oleh sekolah guna menyesuaikan dengan keadaan dan kondisi sekolah. RPP merupakan pengembangan dari Silabus yang telah dibuat atau yang telah dikembangkan oleh sekolah, rancangan program pembelajaran di bikin oleh guru yang bersangkutan, baik melalui KKG. Hal ini selaras dengan pendapat Susanto (2008:63) menyatakan bahwa Silabus adalah suatu rencana instruksional atau pembelajaran yang dibuat untuk setiap mata pelajaran yang terdapat distruktur kurikulum. Silabus disusun untuk dilaksanakan selama kurun waktu tertentu, satu silabus 
memerlukan penjabaran ke dalam beberapa beberapa RPP, yang satu unit pelajaran atau kompetensi dasar suatu mata pelajaran untuk dilaksankan selama kurun waktu pembelajaran tertentu. RPP dibuat berdasarkan silabus. Beberapa bagian dari RPP tidak memerlukan pengembangan, namun beberapa yang lain perlu ditambah dengan rincian atau sesuai dengan keperluan. Penerapan kurikulum dan penyusunan instrumen perangkat pembelajaran di Sekolah Dasar Negeri 14 Mentarau berdasarkan dengan apa yang ingin dicapai dalam proses pembelajaran dengan melihat atau menyesuaikan dengan kondisi dan Keadaan sekolah. Karena Sekolah Dasar Negeri 14 Mentarau dibawah naungan Dinas Pendidikan Kabupaten Kayong Utara, Provinsi Kalimantasn Barat maka dalam proses penerapan kurikulum harus sesuai dengan arahan atau pedoman dan kaidah yang berlaku, jika secara administrasi menggunakan kurikulum ganda yaitu Kurikulum 2013, maka pada tahap implementasinyapun harus menerapkan sesuai dengan ketentuan kurikulum walaupun sarana dan prasarana sekolah kurang mendukung dalam tahap atau ketika dalam proses pembelajaran. Tujuannya agar apa yang direncanakan yang tercantum dalam isi kurikulum bisa tercapai dengan sebagaimana mestinya. Sedangkan pada penyusunan instrumen pembelajaran penerapan Kurikulum 2013 silabus yang digunakan harus menggunakan silabus yang berasal dari pemerintah pusat yang kemudian dijabarkan oleh guru yang bersangkutan untuk dijadikan RPP agar pembelajaran bisa sesuai dengan apa yang menjadi tujuan kurikulum.

\section{Implementasi Program Pembelajaran}

Berdasarkan temuan penelitian yang sudah dipaparkan sebelumnya bahwa Sekolah Dasar Negeri 14 Mentarau secara administrasi menggunakan dua kurikulum yaitu Kurikulum 2013 dan KTSP. Akan tetapi karena kondisi sekolah baik faktor kondisi sarana dan prasanan dan juga faktor Keadaan siswa belum bisa memungkinkan untuk menerapkan Kurikulum 2013, sehingga pada proses pembelajaran lebih dekat dengan menggunakan KTSP. Pendekatan pada proses implementasi program pembelajaran yang sering digunakan oleh guru yaitu pendekatan konsep, pendekatan proses, dan pendekatan kontekstual meurut Suyono dan Hariyanto (2012:18),'Pendekatan pembelajaran adalah suatu himpunan asumsi yang saling berkaitan yang terkait dengan sifat pembelajaran sebagai contoh pendekatan lingkungan, pendekatan ekspositori dan heuristic, pendekatan kontekstual, pendekatan konsep pendekatan keterampilan proses, pendekatan deduktif, induktif, pendekatan sains lingkungan teknologi masyarakat, STM atau STS, dan pendekatan holistic menurut Hamzah (2010),"Pendekatan konsep adalah suatu pendekatan pembelajaran yang bertujuan untuk membantu siswa memahami suatu konsep tertentu". Sedangkan menurut Suyono (2015:59) keterampilan proses secara garis besar dapat dikelompokan menjadi dua yaitu: Keterampilan dasar (observasi, klasifikasi, komunikasi, pengukuran, prediksi, kesimpulan), dan keterampilan terintegrasi (mengidentifikasi variable, menyusun tabel data, menyususn ngrafik, mengambarkan adanya hubungan diantara variable, mendapat dan memproses data, menganalisis alternatif investigasi, menyusun hipotesis, merumuskan variable secara operasional, merancang investigasi, melakukan ekspirimen )".

Implementasi pembelajaran di Sekolah Dasar Negeri 14 Mentarau menggunakan pendekatan konsep bertujuan agar peserta didik bisa memahami suatu konsep dalam hal tertentu, kemudian selain pendekatan konsep juga menerapkan pendekatan proses yang bertujuan untuk membantu peserta didik untuk memahami proses suatu hal yang tertentu, implementasi pembelajaran di Sekolah Dasar Negeri 14 Mentarau selain menerapkan pendekatan konsep dan proses juga menerapkan kontekstual yang bertujuan untuk membantu peserta didik mengaitkan pembelajaran yang diajarkan oleh guru terhadap dunia nyata atau lingkungan peserta didik menurut Sagala (2009:71), "Pendekatan konsep merupakan pendekatan implementas pembelajarannya secara langsung menyajikan konsep tanpa memberi kesempatan kepada siswa untuk menghayati bagaimana konsep itu diperoleh, tanpa harus mengetahui prosesnya. Konsep merupakan buah pememikiran seseorang atau kelompok yang menjadi sebuah definisi sehingga melahirkan produk pengetahuan berupa teori, prinsip, istilah ilmiah, dan hokum". Senada dengan Subiyanto (1990) menyatakan konsep merupakan hubungan dua atau lebih kata. Fungsi konsep adalah untuk menjelaskan dan meramalkan, membuat prediksi. Landasn filsafat pendekatan konsep adalah behaviorisme dengan mengedepankan Teori Stimulus dan Respon (S-R). Sedangkan menurut Suyono (2015). Pendekatan kontekstual merupakan konsep belajar yang bertujuan membantu guru mengaitkan antara materi yangdiajarkan dan situasi dunia nyata siswa dan mendorong 
siswa membuat hubungan antara pengetahuan yang dimiliki dan penerapannya dalam kehidupan mereka sebagai anggota keluarga dan masyarakat. Implementasi Pembelajaran di Sekolah Dasar Negeri 14 Mentarau dengan menggunakan pendekatan konsep, proses, dan juga pendekatan kontekstual tidak terlepas dari pendapat parah ahli terkait dengan penggunaan pendekatan pada pembelajaran, agar tujuan pada pembelajaran bisa tercapai sesuai dengan apa yang menjadi tujuan guru dalam mengajar peserta didik.

Proses pembelajaran di dalam kelas di Sekolah Dasar Negei 14 Mentarau menggunakan strategistrategi pembelajaran yang digunakan oleh guru sangat bervariasi dengan cara mengatur tempat duduk siswa, memasang-masangkan siswa dan juga posisi bangku siswa guna menciptakan kondisi yang kondusif pada saat pembelajaran, kemudian dari pada itu guru juga menngunakan strategi mencari referensi sumber belajar yang sesuai dengan materi yang akan disampaikan, dan guru juga melakukan penilaian yang bertujuan untuk mengetahui perkembangan dan kemampuan siswa menurut Gerlach dan Ely (1980)," Strategi pembelajaran merupakan cara-cara yang dipilih untuk menyampaikan metode pembelajaran dalam lingkungan pembelajaran tertentu." Senada dengan Suyono dan Hariyanto (2011) mendefinisikan strategi pembeljaran "rangkaian kegiatan terkait dengan pengelolaan siswa, pengelolaan lingkungan belajar, pengelolaan sumber belajar, dan penilaian untuk mencapai tujuan pembelajaran". Strategi pembelajaran di Sekolah Dasar Negeri 14 Mentarau dengan mengatur tempat duduk siswa, baik dari letak dan posisi bangku siswa maupung dengan memasang-masangkan siswa merupakan cara guru untuk menyampaikan metode pembelajaran agar pembelajaran bisa berjalan dengan mana semestinya sesuai dengan tujuan pembelajaran.

Proses menyampaikan materi pembelajaran atau pada saat mengajar di Sekolah Dasar Negeri 14 Mentaru metode pembelajaran yang digunakan guru dalam mengajar berupa metode ceramah dengan berbicara didepan kelas atau menjelaskan materi kepada siswa secara lisan, selain metode ceramah guru juga menggunakan metode tanya jawab dengan cara memberikan pertanyaan kepada siswa kemudian guru juga memberikan kesempatan kepada siswa untuk menjawab pertanyaan dari temanteman sekelasnya yang kemudian jawaban dari siswa-siswa akan diperkuat atau diperjelaskan lagi oleh guru, guru juga memberikan penugasan terstruktur kepada siswa guna menggukur sejauh mana kemampuan siswa dalam menyerap pembelajaran yang telah disampaikan. Untuk mengasah atau melatih kemampuan siswa guru menggunakan metode latihan, dan metode diskusi kelompok menurut Suyono dan Hariyanto (2011) metode pembelajaran adalah seluruh perencanaan dan prosedur maupun langkah-langkah kegiatan pembelajaran yamg sering kali terkait dengan pilihan cara penilaian yang akan dilaksanakan. Motode pembelajaran di Sekolah Dasar Negeri 14 Mentarau yang digunakan guru berupa metode ceramah merupakan sa dalam menyampaikan meteri pembelajaran ke pada peserta didik, metode tanya jawab yang dilakukan guru merupakan cara guru agar adanya interaksi anatara siswa dengan guru, dan siswa dengan siswa agar lingkungan kelas bisa lebih aktif dalam belajar. Selain metode ceramah, dan tanya jawab guru juga menggunakan metode tugas terstruktur dengan bertujuan sejauh mana perkembangan kemampuan siswa dalam belajar. Implementasi pembelajaran di Sekolah Dasar Negeri 14 Mentarau menggunakan kurikulum ganda walaupun secara proses penerapan pembelajaran lebih cenderung dengan menggunakan KTSP karena di pengaruhi oleh faktor keadaan sekolah baik dari keadaan sarana dan prasarana maupun dari keadaan siswa. Pada tahap implementasi pendekatan , strategi, dan metode pembelajaran tidak jauh berbeda pada sekolah lainnya, Sekolah Dasar Negeri 14 Mentaru juga menerapkannya berdasarkan terori yang merujuk pada teoari-teori pembelajaran. Sehingga tujuan pembelajaran bisa tercapai sesuai dengan apa yang diinginkan sekolah atau guru dalam proses pembelajaran.

\section{Evaluasi Program Pembelajaran}

Berdasarkan temuan penelitian yang sudah dipaparkan sebelumnya bahwa evaluasi pembelajaran yang dilakukan guru Sekolah Dasar Negeri 14 Mentarau ada dua jenis evaluasi program pembelajaran yaitu evaluasi sumatif yang mana dimaksudkan evaluasi sumatif yaitu evaluasi yang dilakukan oleh guru guna untuk menentukan hasil dan perkembangan atau kemajuan belajar siswa, dan juga selain evaluasi sumatif guru juga menggunakan evaluasi formatif yaitu evaluasi yang dilakukan oleh guru 
guna untuk memperbaiki dan meningkatkan proses proses belajar dan mengajar menurut Norman E. Gronlund (1976) merumuskan penegrtian evaluasi sebagai berikut: "Evaluasi adalah suatu proses yang sistematis untuk menentukan atau membuat keputusan sampai sejauh mana tujuan-tujuan pengajaran telah dicapai oleh siswa (Evaluasi a systematic process of determining the eten to which instructional bjektives are achieved by pupils).

Senada dengan itu pendapat Wrightsone dan kawan-kawan (1956:16) mengemuankan rumusan evaluasi pendidikan sebagai berikut: Evaluasi pendidikan adalah penaksiran terhadap pertumbuhan dan kemajuan siswa kea rah tujuan-tujuan atau nilai-nilai yang telah tercapai didalam kurikulum (Educational evaluasion is the estimation of the growth and progress of pupil toward objectives or values in the curriculum). Senada dengan Hamid (2011:82)," Penilaian sumatif adalah evaluasi yang bersifat kumulatif yang digunakan untuk mengukur perkembangan siswa setelah pengajaran dan umumnya diberikan diakhir pelajaran". Penilaian sumatif diadaan secara periodik untuk menentukan nilai tertentu pada waktu tertentu yang akan menilai apa yang siswa ketahui dan yang belum dikuasai. Evaluasi pembelajaran yang dilakukan guru di Sekolah Dasar Negeri 14 Mentarau merupakan evaluasi yang bertujuan untuk mengetahui sejauh mana kemampuan siswa dalam belajar yang bersifat sumatif, selain evaluasi sumatif guru juga melakukan penilain bersifat formatif menuru Hamid (2011:93)," Penilaian formatif adalah bagian dari proses pengajaran yang menginformasikan baik kepada guru maupun siswa tantang pemahaman siswa pada satu titik ketika penyesuaian-penyesuaian bisa dibuat pada waktunya". Penilain yang dilakukan guru di Sekolah Dasar Negeri 14 Mentarau bersifat formatif artinya guru ingin mengetahui tentang pemahaman siswa pada saat proses pembelajaran yang mana itu akan menjadi tolak ukur guru dalam mengembangkan kerangka pengajaran, untuk merubah cara mereka berinteraksi dengan siswa.

Proses evaluasi program pembelajaran pada siswa, guru menggunakan alat atau bentuk evaluasi pembelajaran berupa bentuk tes lisan, yang dimaksudkan dengan tes lisan disini yaitu guru memberikan pertanyaan-pertanyaan terkait materi pembelajaran yang telah disampaikan, selain test lisan guru juga menngunaka tes tertulis berupa memberikan tugas untuk mengerjakan soal-soal pilihan berganda maupun soal jawaban uraian yang biasanya dilakukan pada kegiatan ulangan harian, Ulangan Tengah Semester (UTS), dan juga Ulangan Akhir Semester (UAS) menurut Latip (2018:107)," Penilaian dalam proses pembelajaran berfungsi sebagai alat untuk mendeteksi kesulitan belajar (assessment as learning), penilaian sebagai proses pembelajaran (assessment for learning), dan penilaia sebagai alat untuk mengukur pencapaian dalam proses pembelajaran (assessment of learning ). Teknik penilain pengetahuan, yaitu test tulis, lisan, dan penugasan. Teknik yang dilakukan guru di Sekolah Dasar Negeri 14 Mentarau dalam melakukan penilaian terhadap siswa dengan cara memberikan test tertulis, lisan, dan juga penugasan terhadap siswa guna mengukur penguasaan peserta didik yang mencangkup pengetahuan factual, konseptual, dan prosedural dalam berbagai tingkat proses berpikir.

Aspek-aspek yang dievaluasi berupa aspek proses pembelajaran siswa guna melihat partisipasi siswa dalam mengikuti pembelajaran atau kehadiran siswa, dan keaktifan siswa dalam proses belajar, kemudian guru juga mengevaluasi dari aspek sikap siswa mengenai kedisiplinan siswa terhadap aturan sekolah, sikap menghormati guru dan sesame teman, dan juga aspek pengetahuan siswa meliputi daya serap siswa terhadap pembelajaran. Menurut Latip (2018:52)," aspek penilaian pada proses pembelajaran. Penilaian hasil belajar peserta didik dalam setiap kurikulum yang berlaku berharap ketercapaian kompetensi sikap, pengetahuan, dan keterampilan". Aspek penilain yang dilakukan guru di Sekolah Dasar Negeri 14 Mentarau lebih menekankan pada aspek proses, sikap, dan pengetahuan senada dengan Purwoto (2013) menyatakan bahwa untuk mengetahui kemajuan dan perkembangan serta keberhasilan siswa setelah mengalami atau melakukan kegiatan belajar salama jangka waktu tertentu, Untuk mengetahui tingkat keberhasilan program pengajaran, komponen-komponen yang dimaksud anatara lain adalah tujuan, materi atau bahan pembelajaran, metode dan kegiatan belajar mengajar, alat dan sumber pembelajaran, prosedur serta alat evaluasi, Untuk keperluan dan bimbimbingan dan konsultasi (BK), dan Untuk keperluan pengembangan dan perbaikan kurikulum sekolah yang bersangkutan. Evaluasi program pembelajaran di Sekolah Dasar Negeri1 4 Mentarau menggunakan pendekatan, teknik, dan aspek yang di evaluasi berdasarkan tujuan yang ingin di capai guru dalam pembelajaran, sehingga dari hasil 
evaluasi bisa dijadikan landasan dalam meningkatkan kualiatas pembebelajaran, dan meningkatankan perkembangan sikap siswa, dan pengetahuan siswa.

\section{Faktor Pendukung Pembelajaran}

Berdasarkan temuan penelitian yang sudah dipaparkan sebelumnya bahwa faktor pendukung pembelajaran ada dua sumber yang pertama dari lingkungan internal sekolah dan juga lingkungan eksternal sekolah. Pembelajaran di sekolah tidak terlepas dari adanya Faktor-faktor pendukung pembelajaran. Di Sekolah Dasar Negeri 14 Mentarau ada beberapa faktor pendukung pembelajaran baik yang bersumber dari lingkungan internal sekolah maupun yang bersumber dari lingkungan eksternal sekolah. Faktor pendukung yang bersumber dari lingkungan internal sekolah meliputi dari faktor guru yang secara kompetensi sudah lulusan S-1 semua dan juga dalam proses guru mengajar mempunyai kreatifitas masing-masing guru yang sesuai dengen kondisi di dalam kelas.

Kemudian selain dari faktor guru juga ada dari faktor siswa yang antusiasnya dalam menuntut ilmu mempunyai motivasi yang bagus sehingga dalam kondisi dan keadaan akses jalan atau cuaca para siswa tetap datang kesekolah walaupun harus berjalan kaki dengan jarak dari rumah ke sekolah yang cukup jauh, peran siswa dalam mendukung pembelajaran secara IPTEK daya dukung masih kurang dan untuk faktor pendukung selanjutnya yaitu dari faktor sarana dan prasarana sekolah. Sarana dan prasarana di Sekolah Dasar Negeri 14 Mentarau dari segi bangunan sudah memiliki bangunan sendiri walaupun bangunannya sudah tua, akan tetapi juga telah dibangun beberapa lokal baru untuk dijadikan ruangan kelas, Sarana dan prasarana dalam menunjang proses pembelajaran masih jauh dari pada kata cukup, masih banyak kekurangan baik dari segi sarana maupun prasarananya, kemudian dari segi sarana dan prasarana yang menunjang proses pembelajaran lainya tetap menjadi faktor pendukung pembelajaran walaupun sekolah hanya memiliki sarana dan prasarana yang ala kadarnya . Selain faktor internal juga ada faktor eksternal yang mendukung pembelajaran yang meliputi dari dukungan masyarakat dan dunia usaha dan industri salah satunya dari perusahaan kelapa sawit menurut Kokom (2013:232), "Subsistem dalam pembelajaran ada beberapa komponen yang mempengaruhi pembelajaran yaitu, peserta didik, pendidik, materi, dan juga sarana dan prasarana. Senada dengan Mustiningsih (2017) faktor- faktor yang mempengaruhi sistem pembelajaran, yaitu sebagai berikut faktor guru, siswa, sarana dan prasarana, dan faktor lingkungan. Faktor pendukung pembelajaran di Sekolah Dasar Negeri 14 tidak terlepas dari ke empat komponen tersebut yaitu faktor guru, siswa, sarana dan prasarana, dan juga lingkungan. Siswasiswa yang belajar di Sekolah Dasar Negeri 14 Mentarau mempunyai motivasi belajar yang bagus dibuktikannya dengan semangat mereka untuk datang keskolah untuk belajar walaupun dalam keadaan cuaca yang hujan dan akses jalan yang sulit untuk di lewati. Kemudian Guru-guru yang mengajar merupakan guru-guru yang berkompeten yang semuanya telah lulusan S1, kemudian dari faktor pendukung sarana dan prasana walaypun jauh dari kata cukup atau memenuhi kebutuhan untuk belajar tetap saja sarana dan prasana yang ada juga menjadi faktor pendukung dalam proses pembelajaran seperti gedung sekolah dan juga media pembelajaran (papan tulis).

\section{Faktor Penghambat Pembelajaran}

Berdasarkan temuan penelitian yang sudah dipaparkan sebelumnya bahwa faktor penghambat pembelajaran ada dua sumberyang pertama dari lingkungan internal sekolah dan juga lingkungan eksternal sekolah. Faktor penghambat yang bersumber dari lingkungan internal sekolah berupa kurangnya sarana dan prasarana, sarana dan prasarana sekolah masih ala kadarnya masih jauh dari kata memenuhi standar, kemudian faktor penghambat lainnya juga dari faktor kurangnya daya dukung IPTEK siswa, secara umum pengetahuan umum siswa masih kurang, siswa juga masih belum bisa menyerap teknologi, dan juga belum bisa sepenuhnya bisa mencari tahu atau mengakses hal-hal atau perkembangan dunia luar, pengetahuan siswa hanya sebatas di sekitar tempat tinggal mereka, selian faktor sarana dan prasarana juga faktor penghambat pembelajaran yang disebabkan seringnya guru datang terlambat mengajar pada saat cuaca hujan atau pada saat musim hujan karena di pengaruhi oleh faktor akses jalan yang rusak. Sedakngkan faktor penghambat yang bersumber dari lingkungan eksternal sekolah berupa akses jalan, kebijakan kurikulum, dan juga kurangnya daya dukung masyarakat sekita dalam mendukung proses pembelajaran atau menjaga keamanan lingkungan sekolah menurut Kokom (2013:232), "Subsistem 
dalam pembelajaran ada beberapa komponen yang mempengaruhi pembelajaran yaitu, peserta didik, pendidik, materi, dan juga sarana dan prasarana. Senada dengan Mustiningsih (2017) faktor- faktor yang mempengaruhi sistem pembelajaran, yaitu sebagai berikut faktor guru, siswa, sarana dan prasarana, dan faktor lingkungan

Faktor penghambat pembelajaran di Sekolah Dasar Negeri 14 Mentarau pada dasarnya lebih banyak bersumber dari lingkungan internal sekolah yaitu pembelajaran sering tidak berjalan dengan apa yang sebelumnya menjadi tujuan pembelajaran. Akan tetapi faktor eksternal juga menjadi penghambat pembelajaran ketika pada musim tertentu, misalnya musim hujan yang mengakibatkan jalan menjadi berlumpur, licin, dan berlubang, sehingga menghambat guru untuk datang sekolah yang menyebabkan guru datang terlambat dan juga tidak masuk untuk mengajar.

\section{Upaya/Solusi Menangani Faktor Penghambat Pembelajaran}

Berdasarkan temuan penelitian yang sudah dipaparkan sebelumnya bahwa ada dua acara yang dilakukan sekolah dalam menangani hambatan pembelajaran yaitu tergantung dari sumber hambatan baik dari sumber faktor internal maupun dari faktor eksternal sekolah menurut Mulyasa (2007:3),"Pembangunan pendidikan untuk berkontribusi terhadap kelancaran proses pembelajaran setidaknya ada tiga syarat yang harus terpenuhi, yakni; (1) sarana dan prasarana, (2) pendidik, (3) bahan ajaran/buku pelajaran yang berkualitas"., Sekolah Dasar Negeri 14 Mentarau Dalam mengatasi kekurangan sarana dan prasarana yaitu dengan meminta bantuan lebih kepada pemerintah atau Dinas Pendidikan dan juga upaya yang dilakukan sekolah atau guru untuk mengatasi kekurangan media pembelajaran yaitu dengan cara membuat media pembelajaran sendiri atau dengan cara meminjam kepada sesama guru di sekolah lain agar proses pembelajaran bisa berjalan dengan baik dan bisa mencapai tujuan pembelajaran.

Upaya sekolah dalam mengatasi kurangnya daya dukung IPTEK siswa pihak sekolah melakukan sosialisasi kepada orang tua siswa agar memperhatikan proses pembelajaran siswa. Untuk mengatasi akses jalan yang rusak yang menjadi penyebab guru sering terlambat masuk mengajar yaitu dengan cara menyampaikan keluhan baik secara lisan maupun dengan memposting Keadaan jalan ke media massa atau internet. Untuk mengatasi kebijkan kurikulum atau perubahan kurikulum guru mengikuti pelatihan.

\section{SIMPULAN}

Instrumen perangkat pembelajaran berupa Silabus, RPP, Program Tahunan, dan juga Program Semester. Silabus pada Kurikulum 2013 merupakan silabuh yang berasal dari pemerintah pusat atau Dinas Pendidikan pusat, akan tetapi sekolah juga mengembangkan sesuai dengan kondisi sekolah. Sedangkan pada KTSP menggunakan silabus yang dibikin oleh sekolah guna menyesuaikan dengan keadaan dan kondisi sekolah sedangkan RPP merupakan pengembangan dari silabus yang telah dibuat atau yang telah dikembangkan oleh sekolah, RPP di buat oleh guru yang bersangkutan, baik melalui $\mathrm{KKG}$, maupun secara individu.

Implementasi program pembelajaran secara administrasi menggunakan kurikulum ganda yaitu Kurikulum 2013 dan KTSP. Akan tetapi karena kondisi sekolah baik dari faktor kondisi sarana dan prasana dan juga faktor keadaan siswa sehingga pada proses pembelajaran lebih dekat dengan menggunakan KTSP. Pendekatan pada proses implementasi program pembelajaran yang sering digunakan oleh guru yaitu pendekatan konsep, pendekatan proses, dan pendekatan kontekstual. Strategi pembelajaran yang digunakan oleh guru sangat bervariasi yaitu cara mengatur tempat duduk siswa memasang-masangkan siswa dan juga posisi bangku siswa yang bertujuan menciptakan kondisi yang kondusif pada saat pembelajaran, kemudian dari pada itu guru juga menngunakan strategi mencari referensi sumber belajar yang sesuai dengan materi yang akan disampiakan, dan guru juga melakukan penilaian yang bertujuan untuk mengetahui perkembangan dan kemampuan siswa. Guru pada saat menyampaikan materi pembelajaran atau pada saat mengajar metode pembelajaran yang digunakan guru dalam mengajar berupa metode ceramah, selain metode ceramah guru juga menggunakan metode tanya jawab, penugasan terstruktur kepada siswa, dan metode diskusi kelompok. 
Evaluasi program pembelajaran yang dilakukan guru Sekolah Dasar Negeri 14 Mentarau ada dua jenis evaluasi pembelajaran yaitu evaluasi sumatif, dan evaluasi sumatif. Dalam proses evaluasi pembelajaran pada siswa guru menggunakan alat atau bentuk evaluasi pembelajaran berupa bentuk test lisan, test tertulis berupa memberikan tugas untuk mengerjakan soal-soal pilihan berganda maupun soal jawaban uraian yang biasanya dilakukan pada kegiatan ulangan harian, Ulangan Tengah Semester (UTS), dan juga Ulangan Akhir Semester (UAS). Aspek-aspek yang dievaluasi berupa aspek proses pembelajaran siswa guna melihat partisipasi siswa dalam menikuti pembelajaran atau kehadiran siswa, dan keaktifan siswa dalam proses belajar, kemudian guru juga mengevaluasi dari aspek sikap siswa mengenai kedisiplinan siswa terhadap aturan sekolah, sikap menghormati guru dan sesame teman, dan juga aspek pengetahuan siswa meliputi daya serap siswa terhadap pembelajaran.

Faktor pendukung pembelajaran ada dua sumber yang pertama dari lingkungan internal sekolah dan juga lingkungan eksternal sekolah. Sekolah Dasar Negeri 14 Mentarau ada beberapa faktor pendukung pembelajaran baik yang bersumber dari lingkungan internal sekolah maupun yang bersumber dari lingkungan eksternal sekolah. Faktor pendukung yang bersumber dari lingkungan internal sekolah meliputi dari faktor guru yang secara kompetensi sudah lulusan S1 semua dan juga dalam proses guru mengajar mempunyai kreatifitas masing-masing guru yang sesuai dengen kondisi di dalam kelas. Kemudian selain dari faktor guru juga ada dari faktor siswa yang antusiasnya dalam menuntut ilmu mempunyai motivasi yang bagus sehingga dalam kondisi dan keadaan akses jalan atau cuaca para siswa tetap datang kesekolah walaupun harus berjalan kaki dengan jarak dari rumah ke sekolah yang cukup jauh.Sarana dan prasarana di Sekolah Dasar Negeri 14 Mentarau dari segi bangunan sudah memiliki bangunan sendiri walaupun bangunannya sudah tua, akan tetapi juga telah dibangun beberapa lokal baru untuk dijadikan ruangan kelas. Kemudian selain faktor internal juga ada faktor eksternal yang mendukung pembelajaran yang meliputi dari dukungan masyarakat dan dunia usaha dan industri salah satunya dari perusahaan kelapa sawit.

Faktor penghambat pembelajaran ada dua sumber yang pertama dari lingkungan internal sekolah dan juga lingkungan eksternal sekolah. Faktor penghambat yang bersumber dari lingkungan internal sekolah berupa kurangnya sarana dan prasarana, sarana dan prasarana sekolah masih ala kadarnya masih jauh dari kata memenuhi standar, kemudian faktor penghambat lainnya juga dari faktor kurangnya daya dukung IPTEK siswa, secara umum pengetahuan umum siswa masih kurang, siswa juga masih belum bisa menyerap teknologi, dan juga belum bisa sepenuhnya mencari tahu atau mengakses hal-hal atau perkembangan dunia luar, pengetahuan siswa hanya sebatas di sekitar tempat tinggal mereka, selain faktor sarana dan prasarana juga faktor penghambat pembelajaran yang disebabkan oleh guru karena seringnya guru datang terlambat mengajar pada saat cuaca hujan atau pada saat musim hujan karena di pengaruhi oleh faktor akses jalan yang rusak. Faktor penghambat yang bersumber dari lingkungan eksternal sekolah berupa akses jalan, kebijakan kurikulum, dan juga kurangnya daya dukung masyarakat sekitar dalam mendukung proses pembelajaran atau menjaga keamanan lingkungan sekolah. Terdapat dua cara upaya/solusi mengenai faktor penghambat pembelajaran yang dilakukan sekolah dalam menangani hambatan pembelajaran yaitu tergantung dari sumber hambatan.

Upaya/solusi yang dilakukan sekolah dalam menangani kekurangan sarana dan prasarana yaitu dengan meminta bantuan lebih kepada pemerintah atau Dinas Pendidikan. Upaya yang dilakukan sekolah atau guru untuk mengatasi kekurangan media pembelajaran yaitu dengan cara membuat media pembelajaran sendiri atau dengan cara meminjam sesama guru di sekolah lain. Untuk mengatasi kurangnya daya dukung IPTEK siswa pihak sekolah melakukan sosialisasi kepada orang tua siswa agar memperhatikan proses pembelajaran siswa. Untuk mengatasi akses jalan yang rusak yang menjadi penyebab guru sering terlambat masuk mengajar yaitu dengan cara menyampaikan keluhan baik secara lisan maupun dengan memposting keadaan jalan ke media masa atau internet. Untuk mengatasi kebijkan kurikulum atau perubahan kurikulum guru mengikuti pelatihan. 


\section{REFERENCE}

Akbar, S. 2013. Instrumen Perangkat Pembelajaran. Bandung: PT Remaja Rosdakarya.

Ferri, N., Harun, C, Z., Usman, N. 2017. Manajemen Pembelajaran Guru pada SD Negeri 1 Peukan Pidie Kabupaten Pidie. Jurnal Magister Administrasi Pendidikan Pascasarjana Universitas Syiah Kuala. Vol. 5 No.4.

Lincoln, Y. S. \& Gub, E.G.1985. Naturalistic Inquiry.Beverly Hill. Sage Publications.

Mulyasa, E. 2007. Menjadi Guru Profesional. Bandung; Remaja Rosdakarya.

Mulyasa. E. 2016. Pengembangan Implementasi Kurikulum 2013. Bandung: PT Remaja Rosdakarya.

Mustiningsih. 2017. Sistem Belajar Mengajar. Malang: Universitas Negeri Malang.

Sagala, S. 2005. Konsep dan Makna Pembelajaran. Bandung; Alfabeta.

Subiyanto. 1990. Strategi Belajar-Mengajar Ilmu Pengetahuan Alam. Malang: IKIP Malang.

Suyono dan Hariyanto. 2011. Belajar dan Pembelajaran, Teori dan Konsep Dasar. Bandung: PT Remaja Rosdakarya.

Triwiyanto. T. 2014. Manajemen Kurikulum dan Pembelajaran Tingkat Satuan Pendidikan. Malang: Fakultas Ilmu Pendidikan Universitas Negeri Malang.

Widyastono. H. 2015. Pengembangan Kurikulum di Era Otonomi Daerah dari Kurikulum 2004, 2006, ke Kurikulum 2013. Jakarta: Bumi Aksara. 